\title{
Erratum to: Colorimetric assay of lead using unmodified gold nanorods
}

\author{
Guozhen Chen • Yan Jin • Wenhong Wang • Yina Zhao
}

Published online: 15 September 2012

(C) The Author(s) 2012. This article is published with open access at SpringerLink.com

\section{Erratum to: Gold Bull}

\section{DOI 10.1007/s13404-012-0057-6}

Unfortunately, an error occured in the Acknowlegdement.

The correct Acknowledgement is given below.

Acknowledgments This work was financially supported by the National Natural Science Foundation of China (21075079), Program for New Century Excellent Talents in University (NCET-10-0557), and the Program for Changjiang Scholars and Innovative Research Team in University (IRT 1070).

Open Access This article is distributed under the terms of the Creative Commons Attribution License which permits any use, distribution and reproduction in any medium, provided the original author(s) and source are credited.

The online version of the original article can be found at http://dx.doi.org/ 10.1007/s13404-012-0057-6.

G. Chen $\cdot$ Y. Jin $(\bowtie) \cdot$ W. Wang $\cdot$ Y. Zhao

Key Laboratory of Applied Surface and Colloid Chemistry,

Ministry of Education, Key Laboratory of Analytical Chemistry

for Life Science of Shaanxi Province, School of Chemistry

and Chemical Engineering, Shaanxi Normal University,

Xi'an 710062, China

e-mail: jinyan@snnu.edu.cn

G. Chen · Y. Jin · W. Wang • Y. Zhao

China State Key Laboratory of Chemo/Biosensing

and Chemometrics, Hunan University,

Changsha 410082, People's Republic of China 